\title{
18. BASALT DRILLED AT THE VEMA FRACTURE ZONE, DSDP LEG 39
}

\author{
Enrico Bonatti and Keith Hartman, \\ Lamont-Doherty Geological Observatory of Columbia University, Palisades, New York \\ Fabrizio Innocenti, Instituto di Petrografia, Università di Pisa, Pisa, Italy, \\ and \\ Robert Kay, Department of Geology, Cornell University, Ithaca, New York
}

\begin{abstract}
An attempt to drill into lower crust at the foot of the northern wall of the Vema fracture valley resulted in recovery of basalt cobbles beneath about 170 meters of sediment. Maximum penetration into the basalt cobble zone was 13 meters. Data obtained by optical microscopy, electron probe, and major and rare-earth element analysis indicate that the basalts are olivine tholeiites and represent a magma type commonly erupted along mid-oceanic ridges. The basalts were probably erupted originally at the axial segment of the Mid-Atlantic Ridge. The basaltic cobble zone probably represents talus material channeled into the valley from the upper levels of the valley wall.
\end{abstract}

\section{INTRODUCTION}

The main objective of drilling close to the foot of the north wall of the Vema fracture valley was to attempt to sample a section of the lower oceanic crust. This attempt was based on the following two assumptions: (a) a partial section of more or less "normal" oceanic crust is exposed at the north wall of the Vema Fracture Zone valley (where by "normal" crust we mean crust originally emplaced in the active, axial zone of the MidAtlantic Ridge); (b) by drilling close to the foot of the north wall one would bypass a thickness of crust roughly equal to the height of the wall (about $2 \mathrm{~km}$ ), thus allowing one to drill directly into lower crust. Assumption (a) is supported by several lines of evidence which have been discussed by Bonatti and Honnorez (1976). Assumption (b) may also be valid, with some limitations, as suggested by the fact that a variety of gabbros and metagabbros, thought to represent lower crustal material, have been dredged from the Vema north wall (Bonatti and Honnorez, 1976). The drilling attempt was done about 30 to 40 kilometers west of the northern axial Mid-Atlantic Ridge segment, close to the foot of the north wall (Figure 1), allowing for a sediment column above basement thick enough to permit drilling into hard rock. No previous detailed site surveys were available, and the limited time allotted to this site did not permit any extensive survey from the Glomar Challenger. Figure 2 shows the location of the drilling sites relative to the north wall of the Vema Fracture Zone. Three attempts were made. The first one (Hole $353,10^{\circ} 54.90^{\prime} \mathrm{N}, 44^{\circ} 02.25^{\prime} \mathrm{W}$ ) had to be interrupted after drilling into about 380 meters of sediment and before reaching basement, because of a mechanical failure. In the second attempt (Hole 353A) basement was reached after going through a sediment section 168 meters thick. A third attempt (Hole 353B) was made a few hundred meters from Hole 353B (Figure 2); basement was reached below about 170 meters of sediment. In both Holes 353A and 353B the basement consisted of cobbles of fresh basalt. This basalt rubble layer was penetrated for 13 meters at Hole $353 \mathrm{~A}$, and for about 10 meters at Hole 353B. No serious attempt at deeper penetration was made due to time limitations.

\section{DESCRIPTION OF THE BASALT}

The cobbles recovered at Holes 353A and 353B range in diameter from five to about $15 \mathrm{~cm}$; some smaller fragments were also recovered. Some of the cobbles appear to have been partially smoothed by the action of the drill and were probably part of larger cobbles. The cobbles consist exclusively of a dark, fresh, microcrystalline, and glassy basaltic rock. Thin sections of several samples from both holes were microscopically studied. The texture of the rocks varies from aphyric to sparsely phyric. Typically, the samples consist of clusters of elongated platelets and needles of calcic plagioclase (frequently with skeletal habit), and abundant isolated partly euhedral crystals of olivine, partially altered to smectites and chlorites, in a very fine groundmass containing secondary phases, opaques, and glass. The various samples from both holes display a range of textures and degree of crystallinity, but the essential mineralogic characteristics appear to be similar in all the samples. One sample (DSDP 39-353B$1-1,85-92 \mathrm{~cm}$ ) was studied in more detail. This sample has partly euhedral and skeletal microphenocrysts of olivine (ranging from Fo75-85) scattered within acicular or felty aggregates of plagioclase (ranging from $\mathrm{An}_{60-05}$ ) 


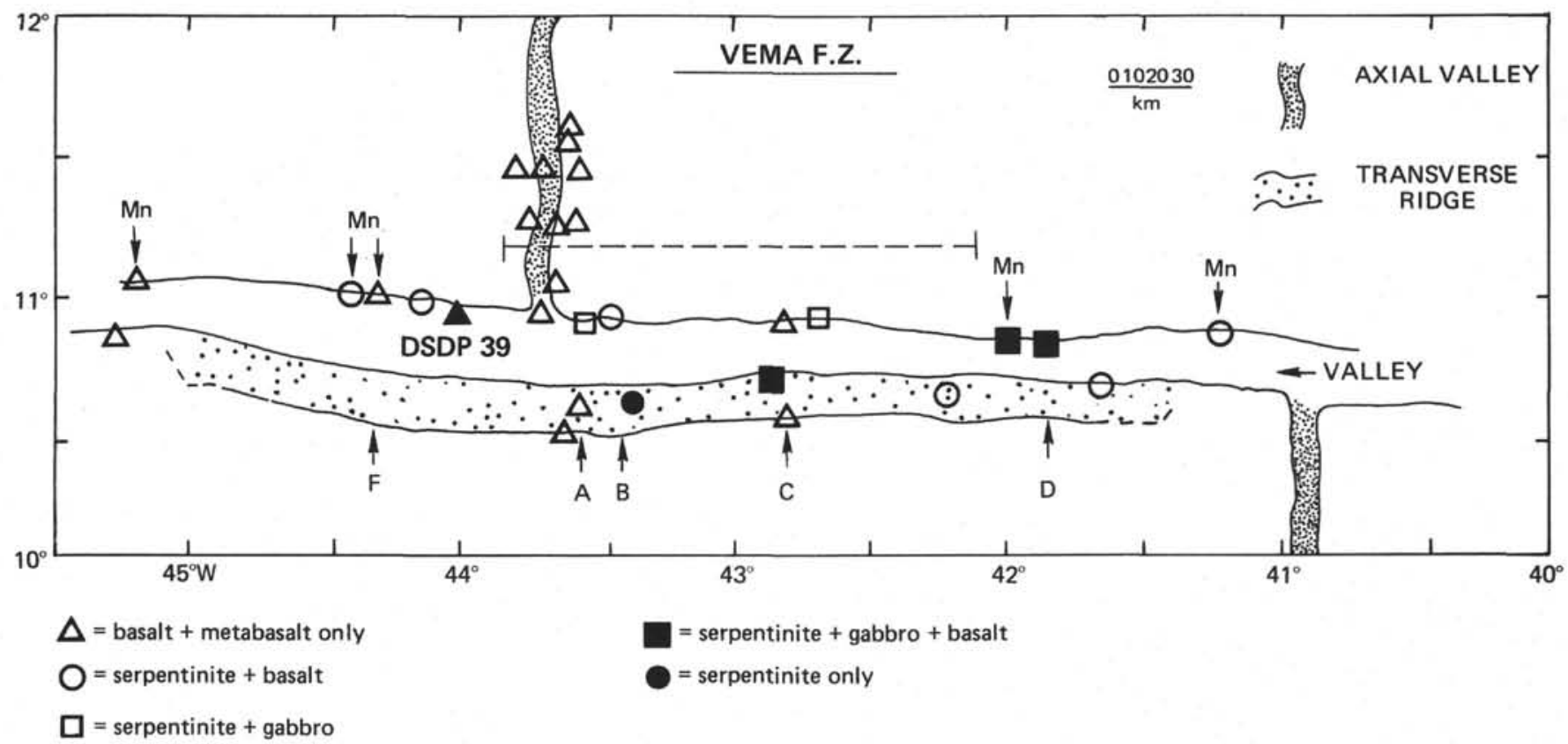

Figure 1. Simplified morphology of the Vema Fracture Zone (after Van Andel et al., 1967), showing the approximate location of drilling sites, Leg 39 and other sites where basalts were dredged.

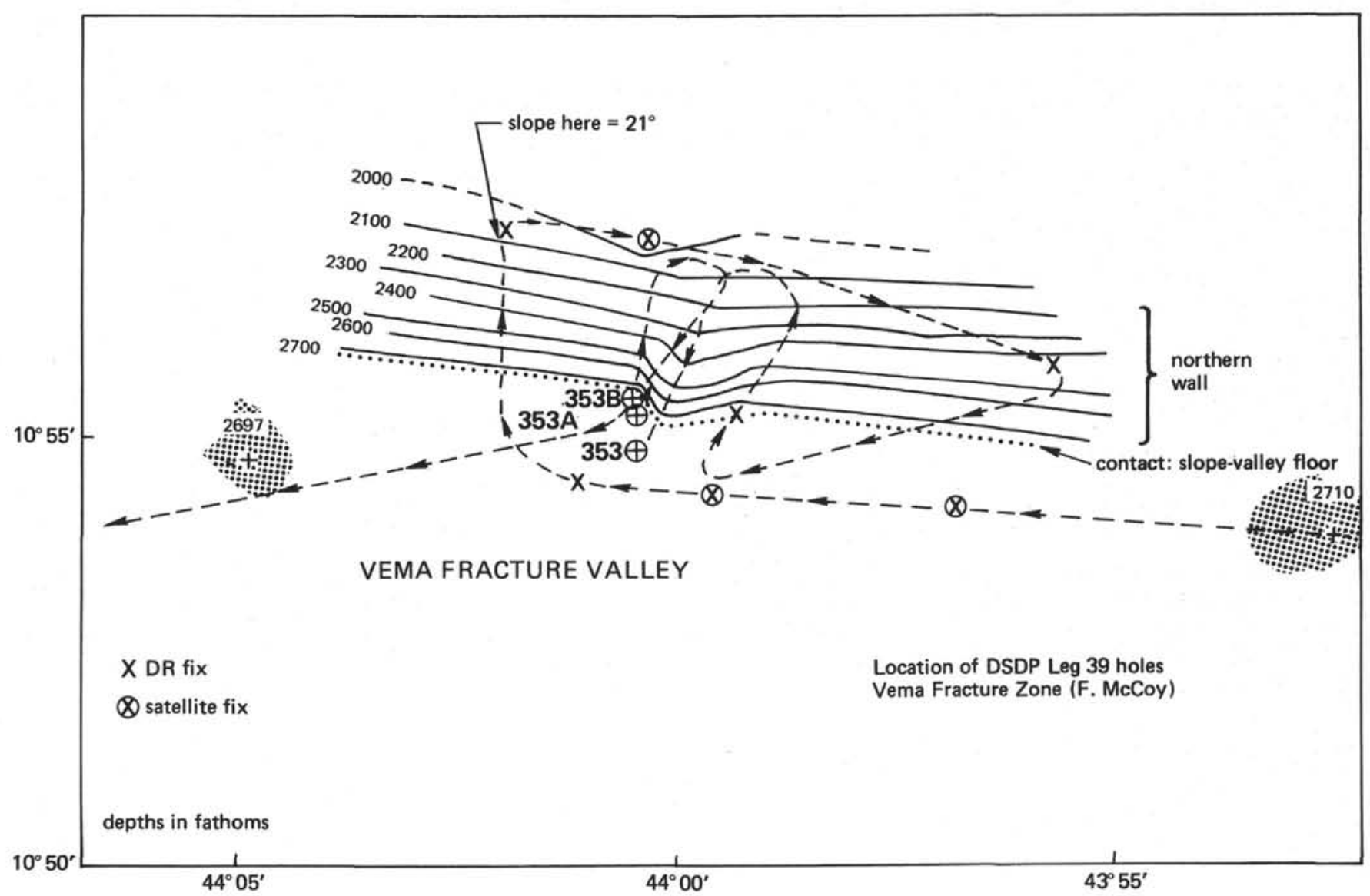

Figure 2. Location of Holes $353,353 A$, and $353 B$ relative to the north wall of the Vema fracture valley. Compilation by $F$. $\mathrm{McCOy}$. 
in a groundmass of fine skeletal plagioclase crystals, opaques, and partly devitrified glass. A distinct olivineplagioclase paragenesis was noted; namely, olivine crystals were observed as nuclei for the radiating plagioclase variolitic aggregates (Figure 3), and in some cases, cross-cutting the plagioclase crystals. These observations suggest that crystallization of olivine preceded that of plagioclase. Electron probe data for some olivine and plagioclase crystals are reported in Table 1. Table 2 shows the results of major and rareearth elemental analysis and CIPW norms of this sample. Major elements were determined by classical methods, rare-earth elements by mass spectrometry, as described in Kay (1970). Shown are also major element data for two other samples from Hole 353B, obtained in the U.S.S.R. by G.C. Kazpe (personal communication).

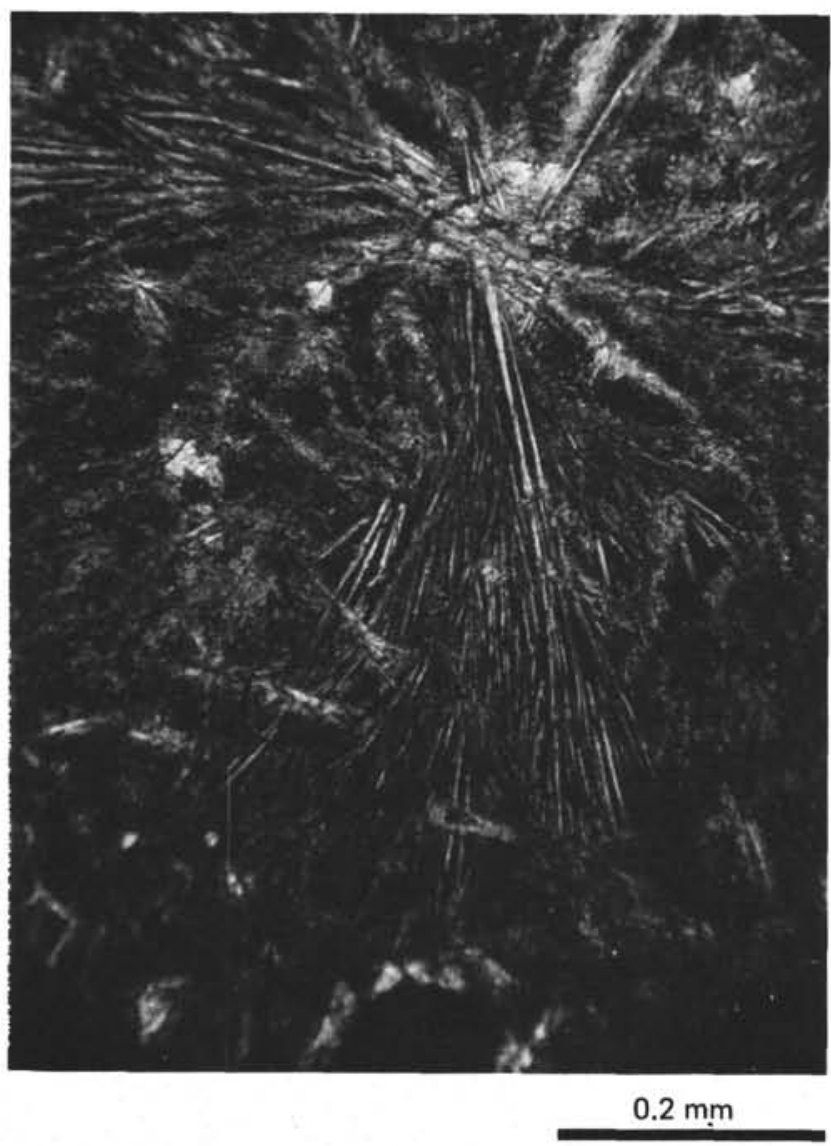

Figure 3. Olivine crystal as nucleus for radiating plagioclase laths. Sample 353-1-1, $85-93 \mathrm{~cm}$.

\section{DISCUSSION}

The mineralogy and chemistry of the basalts drilled at Holes $353 \mathrm{~A}$ and $353 \mathrm{~B}$ are very similar to that of several other basalts obtained on the northern wall of the Vema fracture valley, at various distances from the axial segment of the Mid-Atlantic Ridge, and to basalts obtained within the axial rift valley itself (Bonatti, et al., in preparation). All of these basalts would fall in the olivine tholeiite or quartz tholeiite field of Yoder and
TABLE 1

Major element composition and QPW norms for basalt Sample 353B1-1, 85-93 cm, Concentration of REE also shown.

\begin{tabular}{lrrr}
\hline & \multicolumn{3}{c}{ Composition (in \%) } \\
& $353 \mathrm{~B}-14$ & $353 \mathrm{~B}-5^{\mathrm{a}}$ & $353 \mathrm{~B}-12^{\mathrm{a}}$ \\
\hline $\mathrm{SiO}_{2}$ & 48.60 & 49.97 & 49.62 \\
$\mathrm{Al}_{2} \mathrm{O}_{3}$ & 14.93 & 16.03 & 15.83 \\
$\mathrm{Fe}_{2} \mathrm{O}_{3}$ & 3.51 & 4.17 & 3.97 \\
$\mathrm{FeO}$ & 6.34 & 5.53 & 6.27 \\
$\mathrm{MgO}$ & 8.10 & 8.08 & 7.87 \\
$\mathrm{CaO}$ & 11.32 & 10.26 & 10.82 \\
$\mathrm{Na} 2 \mathrm{O}$ & 2.81 & 2.72 & 2.66 \\
$\mathrm{~K}_{2} \mathrm{O}$ & 0.14 & 0.18 & 0.15 \\
$\mathrm{H}_{2} \mathrm{O}^{+}$ & 1.65 & 0.31 & 0.25 \\
$\mathrm{TiO}_{2}$ & 1.76 & 1.77 & 1.77 \\
$\mathrm{P}_{2} \mathrm{O}_{5}$ & 0.20 & 0.17 & 0.16 \\
$\mathrm{MnO}$ & 0.16 & 0.19 & 0.19 \\
$\mathrm{Total}$ & 99.52 & 99.38 & 99.95
\end{tabular}

\begin{tabular}{lccc}
\multicolumn{5}{c}{ CPW } \\
$\mathrm{Oq}$ & - & 2.05 & 1.21 \\
$\mathrm{Or}$ & 0.83 & 1.06 & 0.89 \\
$\mathrm{Ab}$ & 23.78 & 23.02 & 22.51 \\
$\mathrm{An}$ & 27.72 & 31.01 & 30.82 \\
$\mathrm{Di}$ & 21.81 & 15.00 & 17.52 \\
$\mathrm{Hy}$ & 12.30 & 17.15 & 16.90 \\
$\mathrm{Ol}$ & 2.57 & - & - \\
$\mathrm{Ne}$ & - & - & - \\
$\mathrm{Mt}$ & 5.09 & 6.05 & 5.76 \\
$\mathrm{Il}$ & 3.34 & 3.36 & 3.36 \\
$\mathrm{Ap}$ & 0.44 & 0.37 & 0.35 \\
$\mathrm{La}$ & 2.92 & - & - \\
$\mathrm{Ce}$ & 9.66 & - & - \\
$\mathrm{Nd}$ & 9.60 & - & - \\
$\mathrm{Sm}$ & 3.40 & - & - \\
$\mathrm{Eu}$ & 1.25 & - & - \\
$\mathrm{Dy}$ & 5.50 & - & - \\
$\mathrm{Er}$ & 3.35 & - & - \\
$\mathrm{Yb}$ & 3.10 & - & - \\
$\mathrm{Lu}$ & 0.46 & - & - \\
$\mathrm{Ba}$ & 4.76 & - & - \\
$\mathrm{Ba} /$ Ce & 0.49 & - & - \\
\hline $\mathrm{a}$ Analyses performed by G. C. Kazpe, U.S.S.R.
\end{tabular}

Tilley (1964) normative classification (Figure 4). The chondrite-normalized rare-earth elements pattern from Hole 353B shows light REE depletion typical of oceanridge basalts (Figure 5).

The petrochemistry of basalts from the northern wall of the Vema fracture valley (including those drilled in DSDP Leg 39), is consistent with the assumption that these basalts were originally emplaced at the MidAtlantic Ridge axial segment. Basalts with alkaline affinities and/or a more differentiated chemistry would be expected in the case of within-fracture-zone, "leaky" volcanism (Melson et al., 1967; Honnorez and Bonatti, 1970; Barberi et al., 1975). The hypothesis that the basalts from the Vema fracture north wall were originally emplaced at the Mid-Atlantic Ridge axial segment is supported by indications of an increase in age of these basalts with distance from the MidAtlantic Ridge axial rift valley (Bonatti and Honnorez, 
TABLE 2

Electron probe analyses of plagioclase and olivine crystals in basalt Sample 353B-1-1, 85-93 cm.

\begin{tabular}{|c|c|c|c|c|c|c|c|}
\hline Elements & \multicolumn{7}{|c|}{ Probe Analysis Results (in \%) } \\
\hline \multicolumn{8}{|c|}{ Plagioclase } \\
\hline $\mathrm{SiO}_{2}$ & 53.14 & 54.98 & 53.55 & 53.32 & 53.40 & 54.44 & 54.85 \\
\hline $\mathrm{TiO}_{2}$ & 0.11 & 0.15 & 0.14 & 0.13 & 0.10 & 0.15 & 0.17 \\
\hline $\mathrm{Al}_{2} \mathrm{O}_{3}$ & 29.29 & 27.19 & 29.15 & 28.55 & 28.53 & 27.16 & 27.30 \\
\hline $\mathrm{FeO}$ & 0.82 & 0.84 & 0.72 & 0.90 & 1.02 & 1.22 & 1.17 \\
\hline $\mathrm{MnO}$ & 0.03 & 0.02 & 0.01 & 0.02 & 0.03 & 0.02 & 0.02 \\
\hline $\mathrm{MgO}$ & 0.47 & 0.46 & 0.33 & 0.45 & 0.49 & 0.51 & 0.52 \\
\hline $\mathrm{CaO}$ & 12.13 & 12.44 & 10.97 & 12.54 & 12.26 & 11.60 & 11.89 \\
\hline $\mathrm{Na}_{2} \mathrm{O}$ & 3.75 & 3.70 & 4.66 & 3.88 & 4.07 & 4.32 & 4.04 \\
\hline $\mathrm{K}_{2} \mathrm{O}$ & 0.02 & 0.01 & 0.03 & 0.02 & 0.03 & 0.04 & 0.02 \\
\hline Total & 99.78 & 99.80 & 99.58 & 99.81 & 99.95 & 99.48 & 100.00 \\
\hline \multicolumn{8}{|c|}{ Olivine } \\
\hline $\mathrm{SiO}_{2}$ & 40.18 & 40.54 & 40.16 & 40.31 & 40.47 & & \\
\hline $\mathrm{Al}_{2} \mathrm{O}_{3}$ & 0.58 & 0.22 & 0.22 & 0.27 & 0.24 & & \\
\hline $\mathrm{Cr}_{2} \mathrm{O}_{3}$ & 0.07 & 0.08 & 0.07 & 0.07 & 0.07 & & \\
\hline $\mathrm{FeO}$ & 18.52 & 14.74 & 13.86 & 13.91 & 13.47 & & \\
\hline $\mathrm{MgO}$ & 40.07 & 44.07 & 44.69 & 44.72 & 44.93 & & \\
\hline $\mathrm{CaO}$ & 0.43 & 0.26 & 0.22 & 0.27 & 0.24 & & \\
\hline Total & 100.23 & 99.91 & 99.24 & 99.56 & 99.43 & & \\
\hline
\end{tabular}

1976). Following this assumption, and given a spreading rate from the northern Mid-Atlantic Ridge axial segment of about 1.0-1.2 cm/year (Van Andel et al., 1971; Bonatti and Honnorez, 1976), the age of the basalt drilled at Holes 353A and 353B should be close to $3 \mathrm{~m} . \mathrm{y}$. We interpret the basalt cobbles sampled at

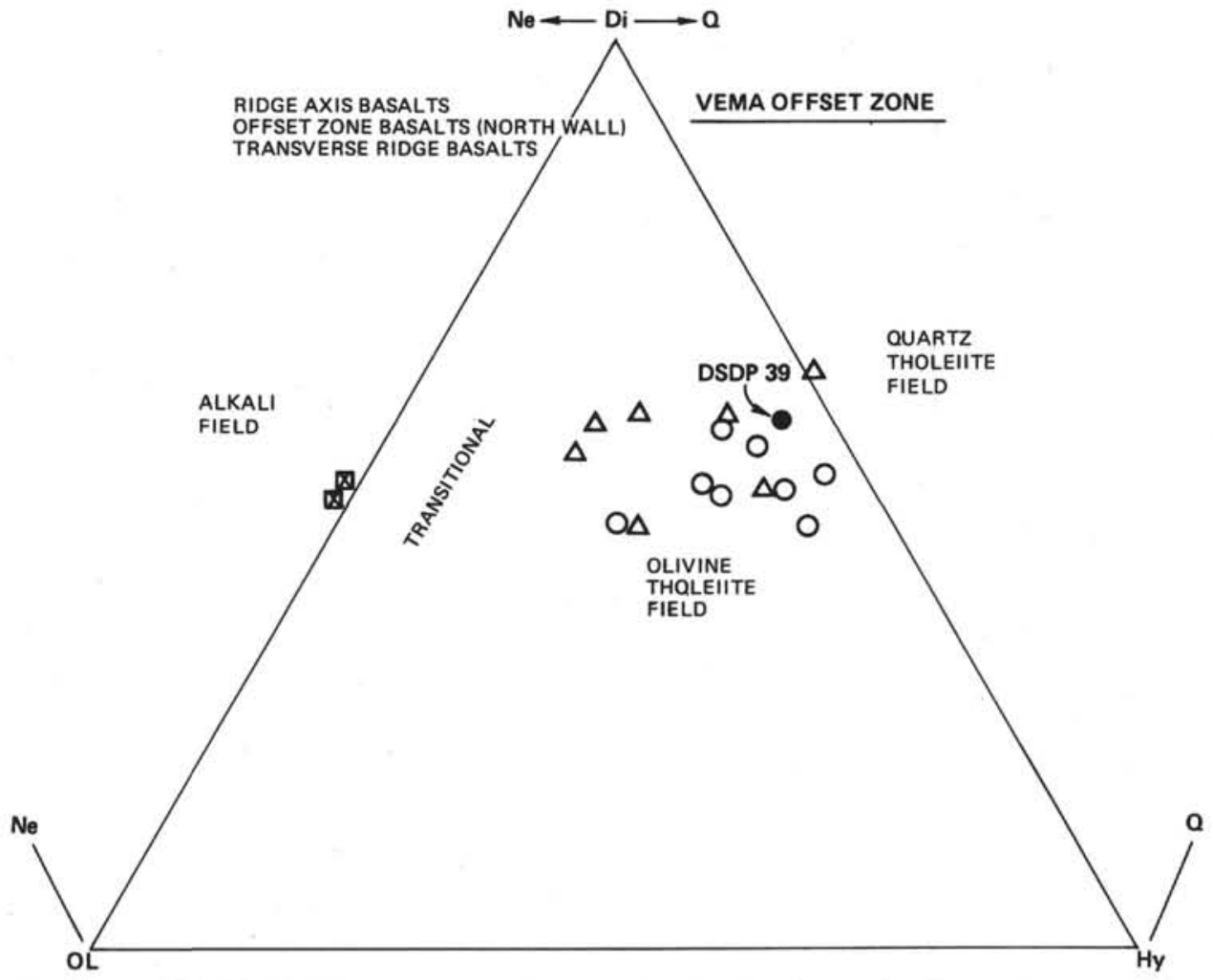

Figure 4. Q-Di-Hy-Ol-Ne normative diagram for basalts from the Vema Fracture Zone including sample 353-1-1, 85-93 cm. Norms were obtained assuming $\mathrm{Fe}_{2} \mathrm{O}_{3}=1.5 \%$. (from Bonatti et al., in preparation). 


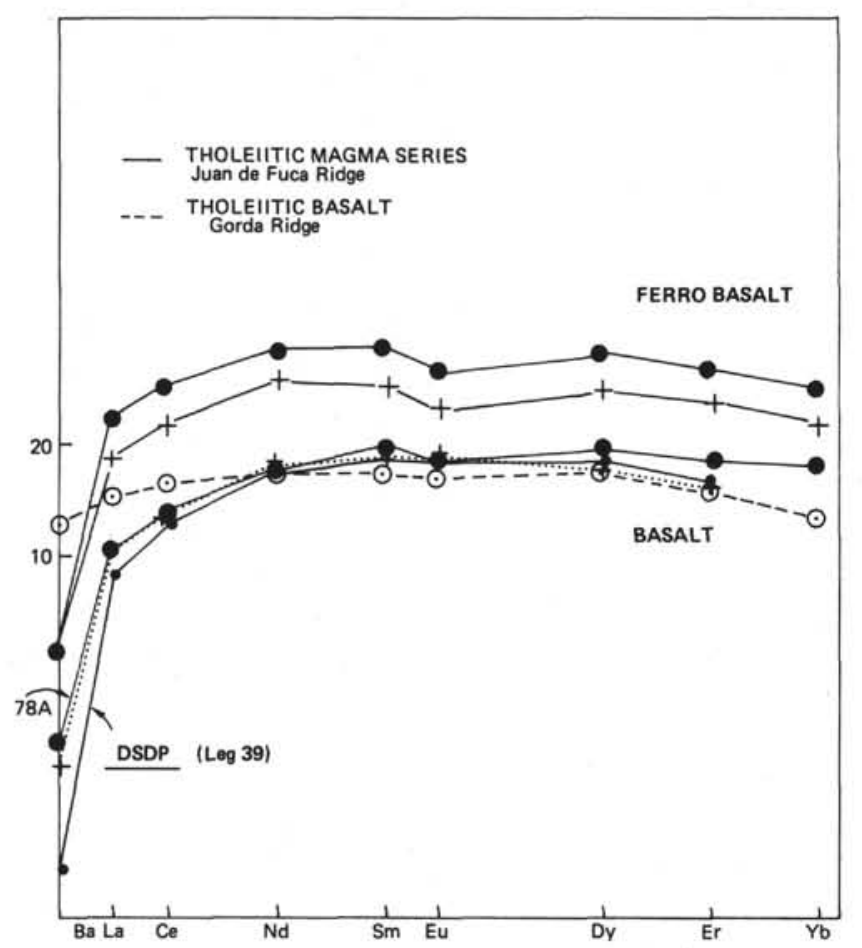

Figure 5. Chondrite-normalized rare earth pattern for basalt $353 B-1-1,85-93 \mathrm{~cm}$, compared with pattern for Gorda and Juan de Fuca ridge basalts (from Bonatti et al., in preparation).

Holes $353 \mathrm{~A}$ and $353 \mathrm{~B}$ as part of a zone of talus material which was fed into the Vema fracture valley from the upper part of the northern wall.

Dredge hauls collected from the slopes of the northern wall in the vicinity of the drilling sites indicate that serpentinized peridotites are exposed on the wall. These dredge hauls include Station A-II-20-8 from Melson and Thompson (1971), located about 5 kilometers west of the drill sites, and station P7003-09 from Bonatti and Honnorez (1976) located about 30 kilometers west of the sites. Gabbros and metagabbros were recovered at several sites on the north wall (Bonatti and Honnorez, 1976). Given the presence of serpentinite on the wall, it is surprising that no fragments of serpentinite or of other plutonic rocks were found in the talus material drilled at Site 353. A possible explanation of these findings is that the talus from the upper basaltic portion of the northern wall is fed to the transverse valley preferentially along southfacing shallow channels or "canyons." Some indication of the existence of such shallow channels can bee seen in van Andel et al. (1971) topographic map of the area under discussion. It is possible therefore that the talus material is not homogeneously distributed along the foot and the lower part of the slope but that it is thicker beneath the channels, and thin or absent away from the channels. If this interpretation is correct, the relatively thick talus encountered at Site 353, containing no serpentinite or other plutonic rocks, coupled with the presence of serpentinite close-by on the wall, might indicate that the drilling was done unforeseeably in an area close to the exit of one of the channels feeding talus to the Vema transverse valley. Post-site evaluation of topographic lines indeed suggests that the drilling was done in one such area, as shown in Figure 1.

These considerations suggest that the original objective of drilling at Site 353, namely, to obtain a section of the lower oceanic crust, bypassing the upper crustal basaltic layer in the Vema Fracture Zone, is still a viable objective, despite our failure to accomplish it during Leg 39. A successful accomplishment of drilling into section of oceanic lower crust at the Vema Fracture Zone will require, in addition to detailed preliminary surveys of the area, a time expenditure at the site larger than that afforded in Leg 39.

\section{ACKNOWLEDGMENTS}

Figure 2 was compiled by F. McCoy. Research was supported by NSF/IDOE and ONR.

\section{REFERENCES}

Barberi, F., Bonatti, E., Marinelli, G., and Varet, J., 1974. Transverse tectonics during the split of a continent: data from the Afar Rift: Tectonophysics, v. 23, p. 17-29.

Bonatti, E. and Honnorez, J., 1976. Sections of the Earth's crust in the equatorial Atlantic: J. Geophys. Res., v. 81, p. 4104-4116.

Bonatti, E., Honnorez, J., Innocenti, F., and Kay, R., in preparation. Basalts from the Vema Fracture Zone (North Atlantic).

Honnorez, J. and Bonatti, E., 1970. Nepheline gabbro from the Mid-Atlantic Ridge: Nature, v. 228, p. $850-852$.

Kay, R., 1970. The rare earth geochemistry of alkaline basaltic volcanics: Ph.D. Thesis, Columbia Univ., 179 p.

Melson, W.G., Jarosewich, E., Cifelli, R., and Thompson, G., 1967. Alkali olivine basalt dredged near St. Paul's Rocks, Mid-Atlantic Ridge: Nature, v. 215, p. 381-382.

Melson, W.G., and Thompson, G., 1971. Petrology of a transform fault zone and adjacent ridge segments: Phil. Trans. Roy. Soc. London, v. 268, p. 423-441.

Van Andel, T.H., Corliss, J.B., and Bowen, V.T., 1967. The intersection between the Mid-Atlantic Ridge and the Vema Fracture Zone in the north Atlantic: J. Marine Res., v. 25 , p. $343-349$.

Van Andel, T.H., Von Herzen, R.P., and Phillips, J.D., 1971. The Vema fracture zone and the tectonics of transverse shear zones in oceanic crustal plates: Marine Geophys. Res., v. 1, p. 251-283.

Yoder, H.S., and Tilley, C.E., 1962. Origin of basaltic magmas: an experimental study of natural and synthetic rock systems: J. Petrol., v. 3, p. 342-390. 